\title{
Eisenstein and Tarkovsky
}

\author{
By Marina L. Levitina
}

Fall 2007 Issue of KINEMA

\section{EISENSTEIN AND TARKOVSKY: AN UNEXPECTED CONNECTION}

For the majority of film scholars, the names of Tarkovsky and Eisenstein represent an opposition between two radically different approaches to the art of cinema. This opposition has been established by Tarkovsky himself, when he wrote:

I am radically opposed to the way Eisenstein used the frame to codify intellectual formulae. My own method of conveying experience to the audience is quite different. Of course it has to be said that Eisenstein wasn't trying to convey his own experience to anyone, he wanted to put across ideas, purely and simply; but for me that sort of cinema is utterly inimical. Moreover, Eisenstein's montage dictum, as I see it, contradicts the very basis of the unique process whereby a film affects the audience. ${ }^{(1)}$

Here, Tarkovsky was referring to Eisenstein's earlier films such as Strike, Battleship Potemkin, and October, all made in the 1920s when Eisenstein was developing his theory of "intellectual montage." Behind this theory was an idea that two shots edited together can produce a third, new meaning which derives from a "collision" between the two original shots. Thus, a filmmaker can in effect use film shots as a kind of hieroglyphs, which make up a new language. ${ }^{(2)}$ Using this linguistic aspect of cinema, according to Eisenstein's theoretical writings of the $1920 \mathrm{~s}$, provides a filmmaker with an ability to influence the viewers' thought processes, guiding them in a premeditated intellectual direction. ${ }^{(3)}$

Tarkovsky, on the other hand, was a proponent of a natural temporal flow within individual shots as the main formative element of cinema. For him, editing did not bring out a new quality, but rather, amplified a quality already inherent in the shots that were being joined. Thus, an individual shot, which could last for several minutes without a single edit, was given priority over montage. ${ }^{(4)}$

The seemingly vast difference in the aesthetic approaches of Eisenstein and Tarkovsky appears to have at least one possible explanation. Eisenstein's ideas on "intellectual montage" were developed within the context of the Soviet avant-garde aesthetics of the 1920s, when the influence of modernism and emphasis on the fast-paced rhythm of life combined with rigorous experimentation in artistic form, as well as with the requirements set by the Party on the cinema. Films had to be used as an instrument of propaganda, placing the emphasis on the collective rather than the individual. ${ }^{(5)}$

Tarkovsky's cinematic approach, on the other hand, blossomed during the "Thaw" period of the 1950s, and matured during the 1960s into what Vida Johnson and Graham Petrie have called an "original creative quest, both stylistically and thematically," ${ }^{(6)}$ reflecting such quintessential sixties' concerns as the tragedy of the individual, the attempt to combine the poetic and the naturalistic, and rejection of stereotypes and canons. And by the 1960s, Soviet montage of the 1920s had become a cinematic canon. ${ }^{(7)}$

However, the different historical and cultural conditions in which the two directors worked, did not dictate their aesthetic preferences entirely and should not be viewed as a definitive condition rendering the two approaches irreconcilable. Eisenstein's creative career spanned the period between the early 1920s and mid1940s, extending far beyond the decline of avant-garde aesthetics that coincided with the acceptance, in 1934, of Socialist Realism as the only officially endorsed artistic method in the Soviet Union. While his cinematic approach did change in the 1930s, Eisenstein did not fully accept Socialist Realism as a new, all-encompassing method. As David Bordwell has argued, Eisenstein attempted "to lift certain premises of Socialist Realism to the realm of serious aesthetic reflection," stressing the importance of informing the new method with a pluralism of styles. ${ }^{\left({ }^{8}\right)}$ Throughout the 1930s and 1940s, he developed new cinematic theories, vastly different from his original theory of "intellectual montage." These new theories included a version of associationism, an idea of "inner speech," and a theory of concept formation assimilating Russian traditions of "thinking in images." (9) They completely displaced Eisenstein's concept of montage from the 1920s. ${ }^{(10)}$ 
One might notice an underlying affinity between these theories that interested Eisenstein in his later years, and Tarkovsky's often stated interest in cinematically portraying subjective experiences, based on associative linking of thoughts and images. According to Tarkovsky,

The usual logic, that of linear sequentiality, is uncomfortably like the proof of a geometry theorem. As a method it is incomparably less fruitful artistically than the possibilities opened up by associative linking, which allows for an affective as well as a rational appraisal. And how wrong it is that the cinema makes so little use of the latter mode, which has so much to offer. ${ }^{(11)}$

A significant factor that complicates the relationship between Eisenstein and Tarkovsky is the fact that the latter's critique of the former is mainly based on Eisenstein's earlier theoretical writings, largely dismissing his later theories. These were little known during Tarkovsky's formative years. (12) Tarkovsky's critique of Eisenstein has thus overshadowed a number of similarities shared by the two directors. In this paper I will attempt to analyze what I consider the main affinity between Eisenstein and Tarkovsky: their desire to portray and express, through the medium of cinema, the subjective experiences of an individual.

In her article Eisenstein and Tarkovsky: A Montage of Attractions, Vida Johnson posits that an affinity between the two directors is akin to the Eisensteinian concept of a "montage of attractions," where "contrasting elements of Eisenstein's cinematic style are borrowed and reconfigured by Tarkovsky." (13) She mentions Tarkovsky's two early films, Steamroller and Violin and Ivan's Childhood, as examples of an editing style largely inspired by Eisenstein's montage films. More importantly, Johnson points out that among Eisenstein's later theoretical writings was the book Nonindifferent Nature which stressed the importance of the "organic unity" of works of art and the "natural world" they reflected - a concept very similar to Tarkovsky's "organic unity of the image" born of "direct observation of life." ${ }^{(14)}$ Briefly touching upon the fact that both artists "wanted to create an emotional as well as physical reality," she delineates three areas of potential influence of Eisenstein on Tarkovsky, including cinematic mise-en-scene, sound, and the historical film genre. Focusing mainly on comparing Eisenstein's Ivan the Terrible and Tarkovsky's Andrei Rublev, Johnson concludes that the latter would not have been possible without the former. ${ }^{(15)}$

Another scholar of the connections between Eisenstein and Tarkovsky, Andrew Barratt, has also limited his discussion of the issue by comparing Ivan the Terrible and Andrei Rublev. According to Barratt, the similarity between the two artists lies in the fact that these two films are based on the opposition between a suffering individual (Ivan and Rublev) and the "undifferentiated mass which is the Russian people," with both artists appealing to the Russian religiosity. ${ }^{(16)}$

Neither one of the two scholars offers an in-depth analysis of the highly significant connection between Tarkovsky and Eisenstein that lies in their mutual interest in cinematic portrayals of the inner states of an individual. In Tarkovsky's case, this interest is more widely known, both from his theoretical writings collected in the book Sculpting in Time and from his films - especially Mirror, which is based on a narrator's memories, dreams, thoughts, and emotional experiences. In the case of Eisenstein, this interest in portraying subjective experiences is not acknowledged nearly as widely. Nevertheless, it is documented in his vast theoretical writings of the 1930s and 1940s, as well as in scripts which have never been made into films, including the script for An American Tragedy. ${ }^{(17)}$

Eisenstein's interest in cinematically portraying the inner world of characters has developed largely under the influence of the modernist literary works of the Irish writer James Joyce. In 1928, Eisenstein read Joyce's Ulysses. ${ }^{(18)}$ A year later, on November 30, 1929, during their meeting in Paris, Joyce showed Eisenstein the scheme of Ulysses, which represented a map of a universal city and the outline of a human life, with episodes of the novel corresponding to an organ of a human body, a colour, a concrete art and a concrete science, and including various other correspondences. According to Oksana Bulgakova, Joyce's novel had such a profound effect on Eisenstein that his theoretical model of the 1930s - which replaced his first model of "intellectual montage" - was largely influenced by these new ideas on universal correspondences. ${ }^{(19)}$ Now, rather than using conflict and contrasts, Eisenstein used such concepts as unity, synthesis, ecstasy, organicity (being derived from nature), and image, as the building blocks of his new cinematic method. He referred to nature as having been structured by a unity, which could not be "intellectually understood, but only sensually and ecstatically experienced." (20) 
In the book Montazh (1937), Eisenstein dedicated a whole chapter to Joyce's Ulysses. He characterized the novel thematically as "an interconnection of documented events with an interior monologue of the one who goes through these events, and with those who[se lives] the main character passes through as an event." (21) The key to Eisenstein's fascination with Joyce may be found in the "interior monologue" device, which Joyce uses to convey the experiences of Leopold Bloom. The readers are presented both with descriptions of Bloom's exterior actions and of his interior reality, his thoughts and state of mind. This device is described by Eisenstein as constructed of "polyrhythmia, simultaneity, [and] multiperspectivity (poliritmija, simul'tannost', mnogoplannost')."(22)

Every word in Joyce works as a whole table of perspectives, meanings, and levels of associations: from the crudest means of physiological sound combinations, rising via two or three levels of regular images to any kind of suprastructural readings that echo reminiscences, associations, and the dialogue between meanings and feelings. ${ }^{(23)}$

Eisenstein's interest in the Joycean polyphonic interior monologue device was realized in his script of $A n$ American Tragedy, written in 1930 while on a trip to Hollywood, soon after his meeting with Joyce. The script, which was based on the novel by Theodore Dreiser and which, in the end, was never made into a film, contained a scene that portrayed an interior monologue of the main protagonist, Clyde Griffiths. Eisenstein credited Joyce with reaching "the absolute perfection" of the literary interior monologue in Ulysses. However, he believed that this device would be able to realize its full potential only in cinema. ${ }^{(24)}$ In fact, he wrote that during their meeting in Paris, Joyce expressed an intense interest in Eisenstein's plans for the use of an "interior cinemonologue," whose potential was much greater than that of its literary predecessor. ${ }^{(25)}$

Eisenstein described his plans for the cinematic rendition of Clyde Griffiths' interior monologue in the following manner:

Like thought itself [the montage lists] sometimes proceeded as visual images, with sound, synchronized or non-synchronized, sometimes as sonority, formless or sound-imagistic: object-representational sounds...

now suddenly as the coinage of intellectually formed words, pronounced just as "intellectually" and dispassionately, with the black screen of rushing imageless visuality...

now as passionate disjointed speech, nothing but nouns or nothing but verbs; then as interjections, with the zigzags of abstract shapes hurrying along in synchronization with them...

now visual images raced past in complete silence...

now joined by a polyphony of sounds,

now by a polyphony of images.

Then both of these together.

Now interpolating themselves into the external course of action, then interpolating elements of the external action into themselves...

as if representing the interior game, a struggle of doubts, outbursts of passion, and the voice of reason, in fast or slow motion, marking the difference in rhythms of each one, and being contrasted together with the almost absent external action: juxtaposing the fever of inner debates with the stone-like mask of the face. ${ }^{(26)}$

The idea of being able to cinematically portray the inner state of a person excited and inspired Eisenstein. He argued that the true material of a sound film is not dialogue, but "monologue."(27) As we have seen, by "monologue" Eisenstein meant an entire range of inner thoughts, feelings, and associations in all their polyphony (which almost begs to be described as a cinematic counterpart of Bakhtinian literary heteroglossia).

As we can see from the first sentence of the quoted paragraph, the way this polyphony of an interior monologue was to be realized cinematically, was through montage. In the same 1932 article in which Eisenstein described his script of An American Tragedy, he stated that he was now convinced that "montage as a structure is a reconstruction of the laws of the thinking process." (28)

Ideas on portraying a character's subjective experience in cinema can also be found in the theoretical writings of Andrei Tarkovsky. In Sculpting in Time, Tarkovsky writes, "A picture has to be naturalistic... What then, you may ask, of the author's fantasies, what of the interior world of the individual imagination, how 
is it possible to reproduce what a person sees within himself, all his dreams, sleeping and waking?"(29) He continues,

The meaning of the scene cannot be concentrated within the words spoken by the characters... For usually a person's words, inner state and physical action develop on different planes. They may complement, or sometimes, up to a point, echo one another; more often they are in contradiction; occasionally, in sharp conflict, they unmask one another. And only by knowing exactly what is going on and why, simultaneously, on each of these planes, can we achieve that unique, truthful force of fact of which I have spoken. ${ }^{(30)}$

Just as Eisenstein stresses the contrast between "the fever of interior debates" and "the stone-like mask of the face," Tarkovsky emphasizes the contradiction between the different planes of a person's inner state and physical action. Both acknowledge the importance of portraying this contradiction cinematically. For Eisenstein, it can be portrayed through such devices as "polyphony of sounds," "polyphony of images," "fast and slow motion," or "visual images in complete silence."As we shall see shortly, Tarkovsky used some of the same devices in his films when portraying a character's inner state.

As we have seen from the Clyde Griffiths' interior monologue description, Eisenstein was planning to use fast and slow motion in order to show the "difference in rhythms" between the outbursts of passion and the voice of reason. Tarkovsky, too, used slow motion in scenes in which a particular emotional state had to be conveyed. For example, a scene in Mirror where a bird lands onto the head of Asafyev, a little boy from Leningrad, is rendered in slow motion. While for Tarkovsky, slow motion is far from conveying "the voice of reason" as contrasted with "outbursts of passion," it nevertheless has a similar function of emphasizing the difference - between the inner emotional state of a suffering individual and the harsh exterior everyday reality. The emotional intensity of the scene, portrayed from the universal point of view of Brueghel's paintings, is expanded by an eerie musical sound mix and by intercutting of the Brueghelian shot with newsreel images of explosions, the dead body of Hitler, nuclear explosion, and other painful images of war. This cut to newsreel images provides a glimpse into Asafyev's state of mind. The shots of a nuclear explosion represent not so much a memory - although it could be a memory acquired through the media - as the character's painful emotions. These emotions are then emphasized by the slow motion shot of a little bird that lands on the boy's head, as if blessing him. ${ }^{(31)}$

While in his theoretical writings Tarkovsky vehemently opposed Eisensteinian montage aesthetic, in practice, when cinematically portraying a person's subjective experiences - consisting of memories, daydreams, dreams, and associative thinking - Tarkovsky often used... montage! In fact, when explaining his cinematic approach to portraying inner experiences, Tarkovsky wrote of the necessity to convey them through "unusual and unexpected combinations of, and conflicts between, entirely real elements."(32)

Let us consider the "Spanish" sequence in Mirror. A number of Spanish men and women, who were brought to the Soviet Union as children in order to escape the Civil War in their country, gather at the Moscow apartment of Alexei, the film's main protagonist. The Spaniards reminisce about their long lost childhood, as one of them begins to playfully imitate a famous matador at a corrida. The filmmaker focuses on the inner experiences of Louisa, a Spanish woman sitting quietly in a chair while the man describes the corrida of his childhood. At one point, we are shown a close-up of Louisa, her serious face expressing a subtle hint of emotional pain. Her close-up is suddenly followed by a very quick newsreel shot of soldiers running through the war-torn streets of a Spanish city, which is followed by a cut that immediately brings us back to the present-day action of the scene in the Moscow apartment. As the man's story turns into a description of the painful memory of saying good bye to his father, before being shipped off to the Soviet Union, another quick sepia-coloured newsreel shot is intercut into the present-day narrative of the scene: a young Spanish woman carries a broken mirror in a street ravaged by war. Natalia, the wife of the film's main protagonist, who is also present in the room, asks Louisa if she would ever consider going back to Spain. Louisa's reply is negative: her husband is Russian, and so are her children, they would not be able to live in Spain.

As if wishing to stop the painful conversation, Louisa gets up and leaves the room. In a quick close-up outside the apartment's door, she turns away, as if to face her own, inner world of memories, painful thoughts and emotions. As soon as she turns, we are presented with a lengthy montage of newsreel footage - as if Louisa is now allowed to fully immerse herself in the inner world of her memories. Bombs are dropped from an 
aeroplane, followed by explosions; children cry as their parents kiss them goodbye and send them off to the Soviet Union. The montage sequence, accompanied on the soundtrack by a heartfelt Spanish song that underlines the sounds of crying, culminates in the shot of a little girl, whose happy face looking straight into the camera suddenly acquires a stern expression, as if she were just beginning to comprehend her future.

This montage sequence signifies a shift from the world of exterior actions to the inner world of the character's memories. As we have seen, montage of shots which are often quite short in duration, is the device chosen by Tarkovsky to express the inner experience of a character. It is precisely those "combinations of, and conflicts between, entirely real elements," which convey the character's state of mind and memories.

The "Spanish" sequence contains a number of elements listed by Eisenstein in his description of an "interior cinemonologue": "visual images with sound, synchronized or non-synchronized" (for example, where the sounds of the present-day conversation in a Russian apartment occur simultaneously with newsreel images of Spanish Civil War); "visual images rac[ing] past in complete silence" (where the sound almost completely fades out to silence in the end of the newsreel footage with Spanish children saying goodbye to their parents; this silence shifts the emotional balance onto the painful images of separation, before a ship horn overwhelms the soundtrack); "[images and sounds] interpolating themselves into the external course of action" (the entire scene is constructed in this way, interpolating present-day action with newsreel images that represent memories); "juxtaposing the fever of inner debates with the stone-like mask of the face" (Louisa's face is largely listless, expressing only hints of the emotional storm that is occurring inside her).

Another element of Eisenstein's interior monologue device, "object-representational sounds," are not present within the Spanish sequence. However, one could argue that they do appear elsewhere in Mirror - in the form of poetry. While poems written by Tarkovsky's father, and read by him on the film's soundtrack, do not necessarily "represent objects," (33) they do represent the character's thoughts and feelings. For example, early in the film, a stranger stops by the mother's house by accident. As he walks away after their brief conversation, and the mother returns to the house, a poem Pervye svidanija begins on the soundtrack, about the young lovers whose love makes them feel as though all of nature is in alignment with them, not knowing what kind of a "razor blade" fate has prepared for them. The poem is read over images of the mother sitting by a window, while it begins to rain outside. As the imagery of the poem intensifies into a powerful portrayal of idyllic love, we see a close-up of the mother with tears running down her cheeks. She is still crying when we hear the last words of the poem:

Birds travelled by the same route as ourselves,

And in the river fishes swam upstream,

And the sky unrolled itself before our eyes,

When fate was following in our tracks

Like a madman with a razor in his hand.

Combining this poem with images of the mother crying as it rains outside her window has an effect of illuminating the mother's subjective emotional state.

For Eisenstein, sound played a big part in the cinematic representation of an "interior monologue." Tarkovsky shared with Eisenstein a strong reliance on sound as a cinematic component. Tarkovsky's goal in designing the soundtrack for Mirror was "to reproduce precise states of mind, the sounds of a person's interior world."(34) The two directors also shared a similar concern for the importance of a relationship between the sound and visual images in a film. Eisenstein's famous theory of "orchestral counterpoint of visual and sound images" was based on the idea that the superimposition of distinct visual and audio elements "doubles up" the power of each component, like a Kabuki theatre enactment of harakiri where the movement of an actor's hand with a knife is made in conjunction with an off-stage sound of sobbing. ${ }^{(35)}$ Eisenstein claimed to have used this idea of an audio-visual counterpoint in a number of scenes in Alexander Nevsky (1938). For instance, when Alexander arrives at Novgorod and offers to take up arms, a bell tolls punctuating his speech, and then punctuating the speeches of the other characters. As David Bordwell points out, while the bell tolls, each following shot becomes one or two musical bars in length; sometimes cuts coincide with the beginning of a new musical phrase, and at other times, they come in on the second accent of the measure. ${ }^{(36)}$

Some scholars point out that whenever he used the word "sound" in his theoretical writings, Eisenstein most 
often meant music. ${ }^{(37)}$ Tarkovsky, too, considered music a highly important element of a film:

"Music does more than intensify the impression of the visual image by providing a parallel illustration of the same idea; it opens up the possibility of a new, transfigured impression of the same material: something different in kind."(38)

We can see that Tarkovsky's views on the combination of music and visual images were very similar to Eisenstein's idea of an audio-visual counterpoint. Arguably, Tarkovsky's application of this idea went even further than Eisenstein's.

The Spanish sequence in Mirror is a good example of Tarkovsky's version of an audio-visual counterpoint. The newsreel images of Spanish children are accompanied by original ambient sound; however, the soundtrack also incorporates the intensely emotional Spanish song and guitar music. The song elevates the newsreel images into a heightened emotional realm. At one point, the sound fades almost entirely. Then we hear a ship's horn, which is followed by a children choir singing a Bach choral piece. The dramatic change on the soundtrack occurs when the images of the Spanish Civil War shift to the images of people flying in air balloons in the Soviet Union. This drastic shift helps put the previous sequence in a larger perspective. It is a shift from the plane of historicity to a different, spiritual plane. It is largely this silent pause - and the gentle choral music, which is in stark contrast with the preceding emotionally charged Spanish music - that triggers this change. The music accentuates the inner, ineffable experience of Louisa and other Spanish men and women: a mixture of memories and nostalgia for their motherland and their lost childhood.

Mirror is often structured around portraying a character's exterior actions juxtaposed with her or his memories, emotions, dreams, interior monologues, and even daydream-like interior dialogues. Sometimes the switch to black-and-white film stock signals this shift from outer to inner experience. During the earring sale scene, the mother is forced to slay a rooster for a meal at the house of a pregnant well-to-do neighbour. Shocked by what she had just done, the mother looks straight into the camera - and there follows a cut to a black-and-white slow motion shot of the father (Oleg Yankovsky) also looking straight into the camera, as if returning the mother's gaze within her mind's eye. In this moment, the mother's inner experience is a mix of memory and imagination. The (inner) dialogue between the mother and the father follows - and then there is a cut, back "out" to the outer world of the present moment where the mother decides to leave the neighbour's house.

Tarkovsky emphasized the importance of even the most minute details when striving to achieve a truthful portrayal of a character in cinema: "Cinema by contrast [with theatre] reproduces a phenomenon in its details, its minutae, and the more the director reproduces these in their concrete, sensuous form, the closer he will be to his aim." (39) One of the elements of Joyce's interior monologue device which was praised by Eisenstein, was "physiological qualities of the detail in close-up."(40) Walter Benjamin has provided us with an insightful analysis of the psychoanalytical potential of cinema in focusing on details that, without cinema, may go unnoticed:

Evidently a different nature opens itself to the camera than opens to the naked eye... The act of reaching for a lighter or a spoon is familiar routine, yet we hardly know what really goes on between hand and metal, not to mention how this fluctuates with our moods. Here the camera intervenes with the resources of its lowerings and liftings, its interruptions and isolations, its extensions and accelerations, its enlargements and reductions. The camera introduces us to unconscious optics as does psychoanalysis to unconscious impulses. ${ }^{(41)}$

Both Tarkovsky and Eisenstein have contributed, one theoretically and the other in practice, to engaging this psychological potential of cinema by discovering cinematic devices of portraying a character's inner experience. Eisenstein was not allowed to put his ideas about interior monologue into practice. Hollywood producers rejected his script for An American Tragedy, while upon his return to the Soviet Union, principles of Socialist Realism, with its disdain for ambiguities, were being actively developed and enforced, not allowing him to implement some of his most radical new theoretical ideas, including the "interior cinemonologue" device. However, even though his theories remained largely on paper, we can say with certainty that Eisenstein was interested in cinematically portraying inner states of mind until the last years of his career. In his 1940 article "Gordost'," he praised James Joyce as having been able to recreate the process of reality being 
reflected and refracted within human consciousness. ${ }^{(42)}$ Earlier, he referred to Joyce as the first messenger of the "cinematography that is to be." ${ }^{(43)}$ In effect, while not being able to implement his ideas in practice, Eisenstein foresaw the future cinema of Andrei Tarkovsky.

According to Ronald Bergan, when preparing to film Leonardo's painting "Young Lady with a Juniper" for a sequence in Mirror, Tarkovsky insisted on using the Leonardo book that used to belong to Eisenstein, and would not use any other one. ${ }^{(44)}$ Perhaps Naum Kleiman is right in arguing that Tarkovsky maintained a love-hate relationship with Eisenstein and rebelled against him as a son against a father. Kleiman had personally witnessed Tarkovsky watching a reconstruction of Eisenstein's unfinished Bezhin Meadow, and described Tarkovsky as being "extremely moved by it despite himself." (45) All his critique of Eisensteinian montage notwithstanding, Tarkovsky seems to have admired Eisenstein and referred to some of his films as being "full of life and poetry." (46) Perhaps his critique would have been less harsh, had he been familiar with Eisenstein's script for An American Tragedy, as well as some of his later theoretical writings and his affinity for the Joycean interior monologue device. The two directors with seemingly very different aesthetic approaches in fact shared certain sensibilities, such as their mutual desire to truthfully portray characters' inner states of mind on film.

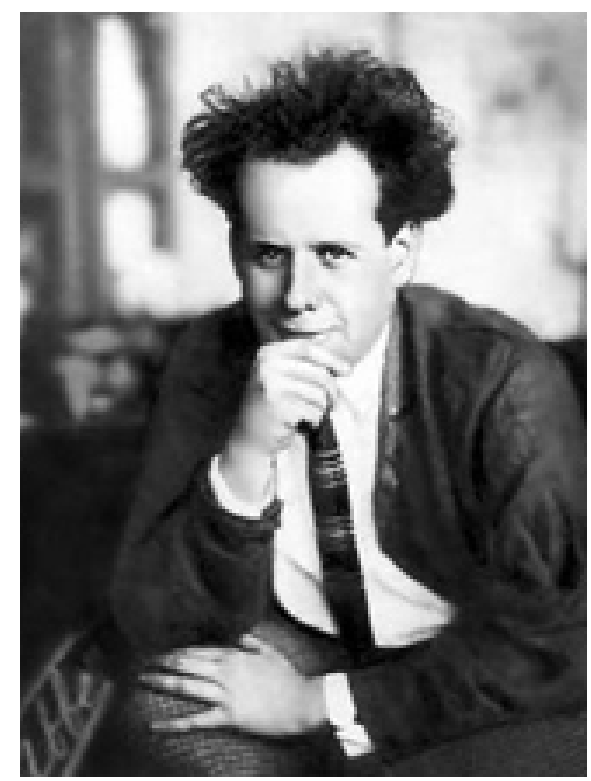

Figure 1: Sergei M. Eisenstein in the 1920s

\section{Notes}

1. Andrei Tarkovsky, Sculpting in Time: Reflections on the Cinema, trans. by Kitty Hunter-Blair (London: Faber and Faber, 1989), 183.

2. Sergei Eisenstein, "A Dialectic Approach to Film Form," in Film Form: Essays in Film Theory, ed. and trans. by Jay Leyda (San Diego: Harcourt, Brace \& Company, 1977), 49.

3. Ibid., 62 .

4. Tarkovsky, 119.

5. Timothy Harte, "Russian Motion: Kinetic Dynamism in Russian Avant-Garde Poetry, Painting and Film," Ph.D. dissertation, Harvard University (May 2001); Richard Taylor, Film Propaganda: Soviet Russia and Nazi Germany, 2nd edition (London: I.B. Tauris Publishers, 1998).

6. Vida T. Johnson and Graham Petrie, The Films of Andrei Tarkovsky: A Visual Fugue (Bloomington: 
Indiana UP, 1994), 14.

7. Lev Anninsky, Shestidesiatniki I my [The Sixties Generation and We] (Moscow: VTPO "Kinotsentr," 1991), 190-196. Quoted in Johnson and Petrie, 14.

8. David Bordwell, The Cinema of Eisenstein (Cambridge, MA: Harvard UP, 1993), 165-166.

9. Ibid., 167-168.

10. Oksana Bulgakowa, "The Evolving Eisenstein: Three Theoretical Constructs of Sergei Eisenstein," in Al Lavalley and Barry P. Scherr, ed., Eisenstein at 100: A Reconsideration (New Brunswick: Rutgers UP, 2001), 44 .

11. Tarkovsky, 20

12. Ian Christie, "Tarkovsky in His Time," in Maya Turovskaya, Tarkovsky: Cinema as Poetry, ed. Ian Christie (London: Faber and Faber, 1989), xviii.

13. Vida T. Johnson, "Eisenstein and Tarkovsky: A Montage of Attractions," in Eisenstein at 100, 162.

14. Ibid.

15. Ibid., 163-167.

16. Andrew Barratt, "In the Name of the Father," in Eisenstein at 100, 150-153.

17. James Goodwyn, "Eisenstein: Lessons with Hollywood," in Eisenstein at 100, 104; Annette Michelson, "Reading Eisenstein Reading Capital, Part 1," October 2 (Summer 1976): 27-38; Annette Michelson, "Reading Eisenstein Reading Capital, Part 2," October 3 (Spring 1977): 82-89.

18. Bordwell, 169.

19. Bulgakova, 43.

20. Ibid., 45.

21. Sergei Mikhailovich Eisenstein, Montazh (Moscow: Musei Kino, 2000), 252.

22. Ibid., 363 .

23. Ibid.

24. Sergei Mikhailovich Eisenstein, "Odolzhajtes'!" in Izbrannye proizvedeniia v shesti tomah [Selected Works in Six Volumes], vol. 2 (Moscow: Iskusstvo, 1964), 78.

25. Ibid., 77.

26. Ibid., 78 .

27. Ibid., 79 .

28. Ibid.

29. Tarkovsky, 71.

30. Tarkovsky, 75. I have added the italics.

31. There is a specific reference in Sculpting in Time to the use of slow motion as a device to portray a character's inner state. On page 110, Tarkovsky writes that he used slow motion in the printing-press scene of Mirror in order "to bring out [the mother's] state of mind through means other than acting."

32. Tarkovsky, 72. I have added the italics.

33. Eisenstein must have meant onomatopoeia by his idea of "object-representational sounds."

34. Tarkovsky, 161-162.

35. Sergei Eisenstein, Selected Works, 1: Writings, 1922-1934, ed and trans. Richard Taylor (London: 
British Film Institute, 1988), 119. Quoted in James Goodwin, "Eisenstein: Lessons with Hollywood," in Eisenstein at 100, 95.

36. Bordwell, 221.

37. Barry P. Scherr, "Alexander Nevsky: Film Without a Hero," in Eisenstein at 100, 219.

38. Tarkovsky, 158.

39. Tarkovsky, 154.

40. Sergei Eisenstein, "Literatura I kino [Literature and Cinema]," in Izbrannye proizvedenia, vol. 5, 526.

41. Walter Benjamin, "The Work of Art in the Age of Mechanical Reproduction," in Illuminations ed. Hanna Arendt, trans. Harry Zohn (New York: Schocken Books, 1968), 237.

42. Sergei Eisenstein, "Gordost' [Pride]", in Izbrannye proizvedeniia, vol. 5, 90.

43. Eisenstein, "Literatura I kino [Literature and Cinema]," 526. Quoted in Alexandar Flaker, "Russian Joyce," in International Perspectives on James Joyce, ed. Gottlieb Gaiser (Troy, NY: The Whitston Publishing Company, 1986), 206.

44. Ronald Bergan, Eisenstein: A Life in Conflict (Woodstock, New York: The Overlook Press, 1999), 355.

45. Ibid., 355 .

46. Tarkovsky, 67-68.

\section{References}

Anninsky, Lev. Shestidesiatniki I my [The Sixties Generation and We]. Moscow: VTPO "Kinotsentr," 1991.

Barratt, Andrew. "In the Name of the Father." In Al Lavalley and Barry P. Scherr, ed. Eisenstein at 100: A Reconsideration. New Brunswick: Rutgers University Press, 2001.

Benjamin, Walter. "The Work of Art in the Age of Mechanical Reproduction." In Illuminations. Ed. Hanna Arendt, trans. Harry Zohn. New York: Schocken Books, 1968.

Bergan, Ronald. Eisenstein: A Life in Conflict. Woodstock, New York: The Overlook Press, 1999.

Bordwell, David. The Cinema of Eisenstein. Cambridge, MA: Harvard University Press, 1993.

Bulgakova, Oksana. "The Evolving Eisenstein: Three Theoretical Constructs of Sergei Eisenstein." In Al Lavalley and Barry P. Scherr, ed. Eisenstein at 100: A Reconsideration. New Brunswick: Rutgers University Press, 2001.

Christie, Ian. "Tarkovsky in His Time." In Maya Turovskaya, Tarkovsky: Cinema as Poetry. Ed. Ian Christie. London: Faber and Faber, 1989.

Eisenstein, Sergei. "A Dialectic Approach to Film Form." In Film Form: Essays in Film Theory. Ed. and trans. Jay Leyda. San Diego: Harcourt, Brace \& Company, 1977.

. "Gordost' [Pride]." In Izbrannye proizvedeniia v shesti tomah [Selected Works in Six Volumes]. Vol. 5. Moscow: Iskusstvo, 1964.

. "Literatura I kino [Literature and Cinema]." In Izbrannye proizvedeniia v shesti tomah [Selected Works in Six Volumes]. Vol. 5. Moscow: Iskusstvo, 1964.

. Montazh. Moscow: Musei Kino, 2000.

"Odolzhajtes?!" In Izbrannye proizvedeniia v shesti tomah [Selected Works in Six Volumes]. Vol. 2.

Moscow: Iskusstvo, 1964.

Flaker, Alexandar. "Russian Joyce." In International Perspectives on James Joyce. Ed. Gottlieb Gaiser. Troy, NY: The Whitston Publishing Company, 1986. 
Goodwyn, James. "Eisenstein: Lessons with Hollywood." In Al Lavalley and Barry P. Scherr, ed. Eisenstein at 100: A Reconsideration. New Brunswick: Rutgers University Press, 2001.

Harte, Timothy. "Russian Motion: Kinetic Dynamism in Russian Avant-Garde Poetry, Painting and Film." Ph.D. dissertation, Harvard University. May 2001.

Johnson, Vida T. "Eisenstein and Tarkovsky: A Montage of Attractions." In Al Lavalley and Barry P. Scherr, ed. Eisenstein at 100: A Reconsideration. New Brunswick: Rutgers University Press, 2001.

and Graham Petrie. The Films of Andrei Tarkovsky: A Visual Fugue. Bloomington: Indiana University Press, 1994.

Michelson, Annette. "Reading Eisenstein Reading Capital, Part 1." October 2 (Summer 1976): 27-38.

. "Reading Eisenstein Reading Capital, Part 2." October 3 (Spring 1977): 82-89.

Scherr, Barry P. "Alexander Nevsky: Film Without a Hero." In Al Lavalley and Barry P. Scherr, ed. Eisenstein at 100: A Reconsideration. New Brunswick: Rutgers University Press, 2001.

Tarkovsky, Andrei. Sculpting in Time: Reflections on the Cinema. Trans. Kitty Hunter-Blair. London: Faber and Faber, 1989.

Taylor, Richard. Film Propaganda: Soviet Russia and Nazi Germany, 2nd edition. London: I.B. Tauris Publishers, 1998.

Turovskaya, Maya. Tarkovsky: Cinema as Poetry. Ed. Ian Christie. London: Faber and Faber, 1989.

\section{Author Information}

Dr Marina Levitina teaches Russian Cinema and Russian Cultural Studies at the University of Dublin Trinity College, and Creative Arts/Engaged Filmmaking at NUI (Galway). Her research interests include early Soviet cinema and culture, the cinema of Andrei Tarkovsky, cinema and memory. She is also a documentary filmmaker. 